\title{
ARTIFICIAL INSEMINATION: A PARVENU INTRUDES ON ANCIENT LAW
}

"It is a wise father that lnows his own child."

-Merchant of Veriec

WHEN the lambent wit of science plays too carelessly with custom, the lords of things-as-they-are have been known to respond with violence-or latterly with more refined coercions. ${ }^{1}$ But even though active opposition to maverick science has been substantially routed, few positive techniques for social adjustment to accelerated change have yet been developed. 2

The problem persistently restates itself. It is a fugue on two recurrent themes: one, the scientific solution of an urgent human need and the other an earlier rationalization for that need. Attempts to apply the new technique create frictions with the former apologia of custom and wont. The interplay of these phenomena explains the present travail of artificial insemination, one of the newer scientific developments of medicine.

While biologically dictated childlessness has long been recognized for its

1. Suppression of scientific advance has appeared in myriad forms and is successful whenever it severs any link between the scientist and the beneficiaries of scientific rescarch. In the 17th Century methods were crass and struck directly at the scientist himself. Giordani Bruno (imprisoned and burned at the stake, 1600); Galileo Galilei (imprisoned under threat of torture; his papers sequestered, 1633).

In more modern times the scientist has been protected by his close association with large and formally organized research institutions. This has not prevented the suppression of scientific discovery however. In fact it is one of the anomalies of Amerimn industry that it is as apt to suppress the products of its research as it is to foster their marketing. For example, the patent grant which was conceived as a catalyst for discovery in 1790 now frequently is made to serve as a bulwark against change and as a prop for stultifying monopoly. Crowther, The Sochal Relatrosts of Serence c. 79 (1941); Hadilton, Patents and Free Enterprise, (TNEC Mlonograph 31, 1941).

Another form of suppression, if the scientist himself seems immune, is to attacls the organs which disseminate his discoveries. This may be accomplished by banning bootss or regulating the facilities and curricula of schools. KrLLEN, The Bermums Russers. CASE (1940); Scopes v. State, 154 Tenn. 105, 259 S. W. 363 (1927).

Finally campaigns against change are frequently addressed to the very persens for whose aid science had acted. Vaccination and birth control are eases in point. At present ecclesiastical institutions are raising barriers against couples who would practice artificial insemination. In 1948 a thirteen-member commission of the Church of England deelared artificial conception through extramarital donorship an "unlawiul intrusion" and "breach of marriage" Catholic authorities have taken a generally similar position. See Kelly, The Morality of Artificial Iisemination, 101 EccLesmastical Rev. 109 (1939). While the various Protestant churches and the Reformed Jewish Church have not yet crystalized their views, it has been surmised that they will probably tend to concur vith whaterer state laws may be passed, but disapproval from the Orthodox Jewish synagogue is anticipated, inasmuch as an orthodox Jewish marriage is only consumated at sexual intercourse. See Abel, Present Status of Artificial Insemination, 85 Suncery, Grriecozogy, AND ObSTETRICs 521 (International Abstract of Surgery) (1947).

2. For a concise statement of the problem see HuxuEy, On Livrig m A Rerozurion vii-xiv (1942). 
frustrations and its dangers, ${ }^{3}$ until recently, science had done no more than ignore the challenge of sterility. ${ }^{4}$ Within the last three decades, however, a medical technique of artificial insemination has been developed which can make childbearing possible in more than $35 \%$ of the $3,000,000$ American marriages now involuntarily barren. ${ }^{5}$

But after the scient ist solved the physiological problem, and the doctor began to relieve the patient, there arose the question of how to accommodate the technique within the traditional legal rationalizations of marriage and procreation. Although the law has not yet definitely spoken against artificial insemination, the mere uncertainty of the new technique's legality has blocked its effective use. Moreover, the powerful inhibition resulting from legal silence has been compounded by a general prognosis that the ultimate verdict will be negative. This is because the actual substance of marriage law is made of unsympathetic accretions from past centuries, and because our legal system lacks positive techniques for making old law adapt to scientific change. Clearly the ensuing struggle will be rife with danger both for doctor and for patient until artificial insemination shall have made its peace with the law.

\section{The Scientific Process}

Not until the 19th Century were the sciences clustered round the art of medical treatment sufficiently freed from commercial casuistry to permit the development of sound biology and scientific pathology. ${ }^{\circ}$ And not until the 20th Century did these new disciplines make serious investigation of the facts of human sterility. ${ }^{7}$ The stimulus for investigation, although stem-

3. The social incentives to procreation are the same as those which lead men to live in social groups and they are particularly akin to those incentives which prompt accumulation of capital and property. Frustration of these incentives has throughout the history of mankind been regarded as evil and curse. SUMNER and KEILER, I THE ScIENCE of Society \& 11, IV The Sctence of Soctety 406 (1927).

4. Nor have Anglo-American common, ecclesiastical or statutory laws concerned themselves with alleviating the frustrations attending barren marriage. Although all three would grant a divorce either amensa et thoro or a vinculo for "impotency," none would dissolve that greater number of marriages barren by reason of "sterility" (lack of procreative power). In fact courts have taken great pains to construe statutes in terms of this dichotomy although the language of the statute has often suggested a contrary meaning. Williams v. Williams, 1 Tenn. Civ. App. (1 Higgins) 538 (1911). Seo also Wilson v. Wilson, $126 \mathrm{~Pa}$. Super. 423, 191 At1. 666 (1937).

5. Approximately one marriage in every ten is barren and scientific studies indicate that in $33-40 \%$ of the cases the cause of the childlessness may be due largely to some deficiency in the reproductive powers of the husband. See Cone, Survey of Prescnt Statiss and Problems of Sterility, 37 TEXAs J. MEd. 20 (1941); Stone, Fcrilitity Services in Planned Parenthood Programs, 10 Human FerTulity 9 (1945); Davis, Stcrility Problem Today, 1 Arr. Pract. 1 (1946). (1934).

6. Malinowski, Introduction to Hogbin, Law and Order in Polynesta liviil

7. The 19th Century tended to view the question of sterility as a matter of conscience rather than as a physical disorder. For example, little more than a life-time 
ming in part from protestations of the barren couples themselves, was and continues in a large measure to be supplied by the anthropologist, sociologist and psychologist. Children are scen as a vital factor in American family life. ${ }^{8}$ Positive attitudes towards having children indicate an increased probability of successful marital adjustment. ${ }^{2}$ Marriages of five years and over are as a general tendency happier where there are one or two children than where there are no children. ${ }^{10}$ And marital unions where children are neither present nor desired rate on the average very low in marital happiness. ${ }^{11}$

Recognizing that more than one in ten married couples are involuntarily barren, medicine has developed a pair of artificial inseminative techniques as an ameliorative practice. Homologous insemination, or $\mathrm{AIH}, 12$ is employed if either penile or vaginal malformation prevents fecundation in an otherwise potentially fertile couple and entails the transfer of the husband's own semen to the wife's reproductive tract. Although an artificial technique, $\mathrm{AIH}$ excites no particular legal problems, since it is impossible to use unless both husband and wife have consented, and since the resulting child is actually their biological offspring. ${ }^{13}$

ago (1869) the eminent Mirion J. Sims was maligned by the MIedical Times and Gazette for his insistence on semen studies in the treatment of sterility. The Mredical Times charged that "this dabbling in the vagina with speculum and syringe is incompatible with decency and self-respect"

It is only within the last forty years that American doctors have seriously bent themselves to the problem, and improved clinical techniques for aiding a barren couple are hardly a quarter-century old in this country.

But see Clifford, Sterility Tests and Thair Morality, 107 Eccussusricnz Rav. 358-67 (1942).

8. Burgess and Cottrelt, Predicting Success or Failute m Matnange 261 (1939).

9. Id. at 366.

10. Lang, Study of Ratings of Martral Happimess 49-50 (1932).

11. BuRgess and CotTreul, op. cit. supra note $\$$, at 261 . For a contrary opinion cee Teracan, Psychological Factors in Marital Happiness 172 (1938).

12. AIH, "artificial insemination homologous."

13. The legal innocuousness of AIH seems universally conceded, and all commentators agree that the only area of legal complication would concern the doctor, and that the rules of conduct evolved in malpractice suits would seem to cover the situation. Mralpractice law simply requires that the practitioner shall have learning and slill commensurate with that of physicians in good standing in the same locality, and that he use ordinary care and diligence in the exercise of that learning and skill. E.g., Johnson v. Borland, 317 Miich. 225, 26 N.W. 2d 755 (1947).

It has been suggested, however, that the law might hold doctors administering AIH to a higher degree of care since such practice is beyond the doctor's duty of preserving the life and health of his patient. 34 VA. L. REv. $\$ 22,823$ (1948). But legal discrimination seems meaningless unless it supposes that ordinary medicine unlike AIH involves only the physical well-being of the patient. Such reasoning can find no comfort in cases involving insanity and nervous disorders where the lack of physical malaise has not given rise to legal differentiation.

For a comprehensive treatment of malpractice law, see HAYT Asid HAYT, LAW of Hospital, Physictan and Patient (1947).

Of some interest, though, is a recent British case (New York Herald Tribune, De- 
The more frequently needed procedure, heterologous insemination or AID, ${ }^{14}$ is used when the wife is fertile and the husband is sterile or has cacogenic hereditary characters. ${ }^{15}$ This technique requires the artificial transfer to the wife's reproductive tract of semen donated by a third person, and the child is not biologically related to the husband. It is this biologic disrelation of husband and child which threatens AID with the wrath of the law. ${ }^{16}$ To understand that threat one must appreciate the extent to

cember 1,1948 , p. 1, col. 3.) in which a court did manage to make a bastard out of a child born via AIH. Artificial insemination did not directly provoke the result. Rather the old saw that annulled marriages must be void ab initio took another child victim. Still the AIH factor in the case did serve to dramatize the especial speciousness of this type of conceptual jurisprudence since the annulment was given on grounds of impotency in the husband. For discussion of the problems surrounding the doctrine of marriages void ab initio, see 30 Cor. L. REv. 877 (1930).

14. Although the name "AID" technically was formed by adding the initials of the phrase "artificial insemination donor" reference to Freudian theories of symptomatic and chance actions perhaps adds another significance to this happy collocation of letters.

15. Detailed articles on the physiological indications for use of artificial insemination are legion in medical literature and seem generally to be in total agreement. See Isracl, Scope of Artificial Insemination in Barren Marriage, 202 Axr. J. MED. Scr. 92 (1941); Abel, note 1 supra; Guttmacher, Role of Artificial Insemination in Human Stcrility, 19 Bull. N. Y. ACAd. Med. 573 (1943); Halbrecht, Artificial Insemitation: 80 Cases, $51 \mathrm{~J}$. Obstetrics and Gynecology, Brit. EMp. 526 (1944); Barton, Walker, Wiesner, Artificial Inseniination, 1945 VoL. I Brit. MED. J. 40; Davis, Sterility Problem Today, 1 Ax, Pract. 1 (1946).

16. To date there have been but three adjudications with respect to artificial insemination on the North American continent. In two of these cases the allusion to artificial insemination was pure dicta. Thus in Orford v. Orford, 49 Ont. L.R. 15 (1921) after finding as a matter of fact that one Hodgkinson had had carnal relations in the ordinary manner with the defendant and that this was sufficient cause to grant a divorce in the ac tion, the court felt constrained to consider heterologous artificial insemination even though it was no longer material to the case. In this gratuitous portion of the opinion the court declared AID to be adulterous.

More recently an Illinois court, in another divorce action in which divorce was again granted on the basis of adulterous sexual relations performed in the traditional physical manner, declared in dicta that AID could never support a judgment that adultery had been committed nor could it therefore support an action for divorce. Sec Hoch v. Hoch, (not reported) (Chicago Sun, February 10, 1945.).

In the third and most recent case, Strnad v. Strnad, 78 N.Y.S. 2d 390 (1948), the problem was at last the subject of a direct holding. In a divorce action the husband-defendant seeking visitation rights defeated the theory of the plaintiff-mother that the child, not being of the blood of the husband, could not stand in a parent-child relationship with respect to the husband. The court ruling narrowly and only with respect to artificial insemination and the right of visitation in divorce cases declared the child for this purpose to stand in identically the same position as a natural born child.

Though artificial insemination's actual bouts with the law have thus far been few and indecisive, the problem has not gone unnoticed in the journals. See Wrigur, Sxuposium on Medicolegar Problems 43-87 (Levinson ed. 1948); Problems in Artificial Insemination (editorial), 48 N. Y. STATE MED. J. 600 (1948); Schatkin, Artificial Insemination and Illegitimacy, 113 N. Y. L. J., 2432 (1945); Abel, sttpra note 1; Editorial on Artificial Insemination, 112 J. Arr. MED. Assoc. 1832 (1939); Seymour and Kocrner, 
which the law of Christian marriage mirrors a cluster of outmoded usages instead of the.present in fact, habit, appreciation and belief.

\section{Marriage, the Law, and AID}

When women's sexual freedom is limited, the field of permissive sex action becomes marriage, and its function is to handle human relationships which exist as a consequence of human bisexuality. Marriage becomes a sort of framework on which personal and group relations having to do with industry, property, war, government, and religion, when these have an element of the sexual in them, are plotted and apportioned. ${ }^{17}$

However, marriage, like other historical institutions, can develop with neither too much of harmony nor logic. And from the Christian nuptial, especially, an ancient formalism has taken its toll. On its arrangements, long since grown rigid, are the marks of the medieval order: "marriage gave support to a caste system resting on landed property, elevated the social values of the family above the individual value of love, was blessed with the ascetic idea of otherworldliness and became a sacrament." ${ }^{13}$ These conventions and values of medieval usage, once ossified in the lockstepping dogma of church and law, have since responded but slowly to eight hundred years of cultural change. Continued application of these outmoded sanctions and trappings to modern circumstance is still, however, both bane and purpose for lawyer and priest.

And medieval schematization metes cruel justice on an urban society where "blood is no longer blue, life is impersonal, children are a luxury, and women must earn their own livings." 19 Quondam answers to the problems of property, social position-inheritance and succession-which automatically came down the trunkline and branchings of blood kinship and the restrictions which have formed as a sort of accretion along the same linesadultery, incest, illegitimacy - are clearly inadequate when applied to the conditions of modern life and particularly when applied to AID.

And for courts who would write and rationalize their opinions, the problem is further aggravated by the fact that both the law and theology when rearing a dialectic for feudal usage arranged their concepts with respect to sex and procreation in pairs of polar opposites. The antipodal postures of adultery-fidelity well illustrate this resistance to thinking in relative

Medicolegal Aspects of Artificial Insemination, 107 J. A2r. AfED. Ass'v 1531 (1936). English comment is much the same as American, the legal problems being identical save for the fact that the English are spared some of the conflict of laws confiusion that our federal system insures. See pp. 469-70 infra. For British comment see Martin, Artifisial Insemination, 34 New Statesaran and Nation 7 (1947) ; Barton, Waller, Weisner, note 15 supra; Forbes, The Mcdico-Legal Astects of Artificial Insenisation, 12 MenreoLEGal and Crmmolmogical Review of England 138 (1944); Halbreet, Arlificial It:semination, 11 HUNAAN FERTILITY 72 (1944).

17. Sumner and Keiler, The Sctence of Soctety $\$ 340$ (1927).

18. Hamilton, Institutions, 8 Excra Soc. Scr. $\$ 4,85$ (1932).

19. Ibid. 
terms. ${ }^{20}$ This made sense in a culture acknowledging but a single incident as exception to the link twixt intercourse and progeny, and which saw its whole authoritative scheme perturbed by infidelity's threat to descent, inheritance and succession. Thus the mores adjusting bisexuality evolved into a marriage-institution whose heavenly ratified bonds could only be burst by adultery. And when a marriage was broken, an intractible deductive logic made the offspring of that adulterous mating filius mullius: a being sans property or status.

The futility of applying these outmoded norms to AID probably shows best in the fact that their use still leaves the result unpredictable. By taking any approbative feudal concept for a major premise and AID's biologic disrelation of the child and its mother's spouse for a minor, the law can advance to such implausible sequiturs as bastardy and adultery. Traditional requirements of legitimacy cannot be met by the child not of the blood of its mother's spouse-the child is therefore a bastard. Legitimacy requires conduct that cannot introduce a false strain of blood into the family of a husband-the mother by AID must be an adultress. ${ }^{21}$ And courts questing for dubious therefores can cut a wide swath. If AID is adulterous, marriage or divorce may hang in the balance. ${ }^{22}$ Visitation rights or the duty of support may depend on the finding of legitimacy. ${ }^{23}$ The doctor can emerge a coconspirator to adultery, liable both criminally and in tort. ${ }^{24} \mathrm{~A}$ fee tail over to issue can fall to or fail with the child born of AID. ${ }^{25}$ Further hardship

20. For a discussion of the law's indifference to the distinction between "logical division and natural classification" see Cohen, The Place of Logic in the Lave, 29 HArv. L. REv. 622 (1916).

21. For examples of courts and commentators convinced by or at least willing to employ these syllogistic exercises, see Orford v. Orford, 49 Ont. L.R. 15 (1921); Wuatur, op. cit. supra note 16; Schatkin, Artificial Insemination and Illegitimacy, 11 HunsaN FERTILITY 14 (1946); Editorial, 112 J. AN. MED. Ass'N 1832 (1939).

22. The dicta in Orford v. Orford, 49 Ont. L.R. 15 (1921), shows the ease with which that court would have rationalized a divorce.

Adultry is recognized as constituting a ground for divorce in nearly every state in the union. Although in some jurisdictions a single act of adultery by the husband is not sufficient to sustain a divorce, a single act by the wife will sustain such an action with hardly any exception. 2 VernIER, AMERICAN FaArily Laws $\$ 65$ (1932).

There are limitations on the granting of divorce for adultery, and these limitations might be interpreted favorably to AID, e.g., where a husband's consent to his wife's adultery vitiates adultery as a ground for divorce, Matchin v. Matchin, $6 \mathrm{~Pa} .332$ (1847); where adultery must be accompanied by desertion, Steel v. Steel, 104 N. C. 631, 10 S. E. 707 (1889); or where condonation is a defense, Cumming v. Cumming, 135 Mass. 386 (1883). Still such exceptions could easily be avoided by an antipathetic court's noting that the limitations were designed to meet other fact situations.

23. Strnad v. Strnad, 78 N. Y. S. $2 d 390$ (1948).

24. For the statement of a barrister willing to push this far see Wricut, op. cit. supra note 16.

25. We have already experienced something akin to the problems AID can raise in cases involving adoption. Courts in interpreting adoption statutes have gone both ways with respect to such testate phrases as "issue of his body," "living issue," "issue," "children," "legitimate children" or "descendant." Generally, however, an adopted child has 
may accrue from the ancient rule that a bastard has no intestate rights in his father's estate. ${ }^{26}$ And who is the father to claim the intestate estate of the child?

But the products of casuistry are never inevitable. The law seems graciously receptive to AID when the judges compare artificial insemination with the feudal norms of adultery instead of fidelity. For example, AID is not literally included within any extant definition of adultery; therefore, it can be reasoned that a woman who practices it cannot be an adulteress and her offspring must be legitimate. ${ }^{27}$ This would follow inevitably if the law would take its basic premise from sex crimes. Then adultery will require intercourse which, as in the lay view, requires sexual penetration by an adulterer measured by the realistic criteria of rape. $\cong$ Since AID can no more square with one set of traditional concepts than the other, selection of

not been allowed to take under a limitation "to the heirs of his body" although an adopted child has been held to take under a limitation to the "lineal descendant" of the adopting parent. See 4 Vernies, Airerican Fanrily Laws $\$ 262$ (1932); 38 Hars. L. Rev. 976 (1924).

26. In accord with the English common law concept which regards the bastard child as filius nullius every American jurisdiction save Connecticut at one time deemed the bastard to be without inheritable blood. While most states have since enacted remedial statutes, these invariably refer to the biologic father and in nearly every instance require acts similar to those leading to legitimation as requisites for allowing rights of intestacy to flow to the bastard.

27. One American court has used this rationale. Hoch v. Hoch (Chioago Sun, February 10, 1945).

28. For cases illustrative of the general rule that penetration is an essential element of rape, see Nider v. Commonwealth, $140 \mathrm{Ky} .684,131$ S. W. 1024 (1910) ; State v. Grubb, 55 Kan. 678, 41 P.951 (1895).

Legal commentators on AID have been distressed by a sentence of Lord Dunedin in the celebrated case of Russell v. Russell, 13 Brit. Rul. Cas. 246 (H. L. App. Cas.) (1924). Here it was said that fecundation $a b$ extra is adultery. Id. at 279. At first blush this generalization would seem to include AID. But study of the facts of the case and one of the basic propositions which underlay Lord Dunedin's comment shows its pertinence to be more apparent than real.

The case was a proceeding for divorce in consequence of adultery and the sole issue at bar was whether a husband or wife is permitted to give evidence of nonintercourse after marriage to bastardize a child born in wedlock. The peculiar factual aspect of the case was that the appellant-wife had admittedly conceived and had a child without penctration by any man; she was fecundated $a b$ extra. In order to get to the principal issue Lord Dunedin said that for himself it mattered not that the corespondent's emission came at the orifice and not within the vagina. An express postulate of the opinion was "that a child cannot be conceived and born to a woman without previous intercourse with a man." Id. at 278. That the justice was thinking of intercourse and carnal lmowledge in its traditional mode speaks for itself; that in such circumstances adultery should not depend upon whether fecundation was a consequence of emission within or without the vagina seems patent. It seems equally patent, however, that the case and the little gloss it puts on traditional concepts of adultery can have no bearing on a fact situation where the entire phenomenon of intercourse in its traditional sense is totally absent and where the policy considerations facing a court are far and away different from those poscd by the Russcll case. 
the initial term controls the result. That initial selection depends primarily on whether the judge feels more moral indignation against the evils of sterility than against the encroachment by science on the legal reserves of family life.

\section{Grace by Indirection}

Some persons, either afraid or dismayed by the rewards of this fickle logic, have sought and found hope in the law's occasional practice of restoring with one hand that which it snatched with the other. It is true that both statute and common law have long had a battery of techniques affecting a return to grace from bastardy. However, none of the traditional methodsregistration of births, adoption, post hoc marriages or acknowledgmentcan rescue the participants in AID. These concepts, designed to achieve desirable ends in fact situations other than those offered by AID, set requirements appropriate to these other contexts but malapropos when applied to heterologous insemination. ${ }^{29}$

For legitimation of a bastard the law looks to the acts of the biologic father. If he will marry the mother or acknowledge the child as his own, legitimacy may be conferred. ${ }^{30}$ But with AID the biologic father is not the proper parent. Moreover, he is usually unknown to the couple and child and they to him. And this secrecy is dictated by important considerations. For example, in some communities the novelty of the technique would mean scandal or acute psychological pain for participants, and these very possibilities are themselves invitations to blackmail. For the continued happiness and security of donor, couple, doctor and child anonymity should be preserved. ${ }^{31}$

Neither can adoption save AID. Here a technique in derogation of the common law has long been burdened with requirements designed to insture the welfare of indigent, homeless children, ${ }^{32}$ and to meet these requirements, even in the instances where they can be met, necessitates nearly total sacrifice of the secrecy that must surround successful practice of AID. ${ }^{33}$ For

29. For an ingenious discussion of how Pennsylvania adoption law might be used to save the child born of AID see Schock, The Legal Status of the Semi-Adopted, 46 Dick. L. Rev. 271 (1942). See also 112 J. Ax. Med. Ass's 1832 (1939).

The court in Strnad v. Strnad, 78 N.Y.S.2d 390 (1948), ran the gamut of saving analogues. It speaks of the child as "semi-adopted," "potentially adopted" and somchow was able to say "the situation is no different than that pertaining in the case of a child born out of wedlock who by law is made legitimate upon the marriage of the interested parties."

30. Madden, Persons and Domestic Relations, 344-7 (1931).

31. Commentators on AID seem unanimously agreed on this point. See Guttmacher, Role of Artificial Insemination in the Treatment of Sterlity, $120 \mathrm{~J}$. AM. MED. Ass'N 442, 445 (1942) ; Barton, Walker, Wiesner, supra note 15, at 41.

32. Kuhlmann, Intestate Succession By and From the Adopted Child, 28 Wasw. U. L. Q. 221, 224 (1943).

33. For a discussion of the myriad problems certain to face a couple and child secking legal sanctuary via adoption, see Schock, supra note 29. 
example, when the adopting parent or parents petition the orphan's court, they must state the name of the child to be adopted. Since the surnames of children are patronymics in our culture, this sets a requirement incompatible with AID whose donor must remain anonymous.

The same problem arises again when the names of the natural parents of the child are requested. In cases where the doctor has kept records these facts could doubtless be determined. However, the consequence of such disclosure would be the elimination of the practice since neither donors nor couples can be psychologically prepared for such an event. A similar name problem arises with respect to the birth certificate. Most states require that both the obstetrician and the parents shall attest to registration statements of parenthood. Where the doctor knows the child to have been born via AID, he must either swear falsely or sacrifice crucial secrecy. And of course the couple is always forced to face this false swearing dilemma.

\section{A Substitute Law}

When the courts and legislators and other agencies regularly charged with maintaining social order failed to deal satisfactorily with AID, the medical profession was forced to improvise in a foreign field. Faced with a legal attitude towards artificial insemination varying from opposition to disregard, the doctors have evolved a body of "ground rules" in an attempt to police the practice and to obtain a degree of self-protection. Rightly noting that the crux of every question that turns on AID is the status of the child or would-be-child with respect to its mother's husband, institutional patterns and ground rules have been developed to attest and bind the mother and husband and child as a family.

For secrecy, if the doctor who inseminates the mother does not care to swear falsely with respect to the husband's paternity, the ground rules categorically advise him to send the couple elsewhere at birth that his brother in ignorance may innocently swear to the false. ${ }^{34}$

Professional opinion divides sharply, though, on the better way to hold the donor, the couple and the child to their proper spheres. One group would use complex, signed, sealed, and fingerprinted bilateral agreements attesting consent to the practice and defining each signator's orbit. ${ }^{35}$ Others would avoid records entirely, premising security on the legal presumption favoring legitimacy, the physician client privilege, and donor and couple selection designed to avoid the litigious. ${ }^{i 6}$

Participants in AID have been advised to draw wills in order to avoid the

34. Abel, note 1 supra.

35. Seymour and Koerner, note 16 supra.

36. Guttmacher, Physicians' Credo for Artificial Inscminalion, 50 West. J. Surgenx 357 (1942); Guttmacher, Role of Artificial Insemination, sufpra note 31, at 445. Dr. Guttmacher takes a rather Olympian view of his relationship to the patient and the law. $\mathrm{He}$ admonishes a doctor to regard himself as an "Aesculapian" administering to "some wretched, worthy, sterile couple" 
pitfalls of intestacy. And clauses have been suggested that would withdraw the share of any who attack on the basis of AID. ${ }^{37}$

But while they have tilted with the existing law, the doctors have also looked to broader social goals than is commonly the legal wont. Medicine has included in its ground rules provisions capable of producing eugenically superior children in better homes than is true in most instances where the child is biologically related to its mother's spouse..$^{38}$

In AID these objectives are achieved by means of a simple operating code which requires that couples showing the biologic indications for heterologous insemination must demonstrate, prior to resort to AID, average or better than average intelligence, ${ }^{39}$ marital and emotional stability, ${ }^{40}$ and absence of serious dysgenic characters in the female. ${ }^{41}$ The couple must also show reasonable financial ability to care for a child, 42 and most important, both spouses must sincerely want to attempt AID.43

Professional concern for the broader eugenic and social aspects is further reflected in the factors which govern donor selection. Here the donor must be physically healthy, have no dysgenic hereditary traits, have a high spermatozoa count and motility index, and resemble the male spouse in racial,

37. Seymour and Koerner, note 16 supra.

38. That this has been generally accomplished is reflected in a varicty of ways. Neither before nor since Seymour and Koerner published their study of 10,000 cases of babies born via artificial insemination (Artificial Insemination: Present Status in the United States, 116 J. AMr. MED. Ass'N 2747 (1941)) has an instance of a biologically inferior child born via the technique been reported.

Some measure of family balance is attested by the paucity of law suits involving the practice. Only three cases, involving artificial insemination, each for divorce have yet arisen in the English speaking world. See note 16 supra. And in each of these instances it may fairly be said that artificial insemination was more a whipping boy for, than the cause of, the divorce.

A variety of reports indicate the generally superior home conditions which medical screening provides children born via artificial insemination. See Halbrecht, note 15 supra; Folsome, The Status of Artificial Insemination, 45 Ax. J. OdSTETrucs AND GYNECOLOGY, 915 (1943). This latter article also contains trenchant criticism of Seymour's and Koerner's 1941 study, supra note 16, at 917-22.

39. Drs. Seymour and Koerner require a Stanford-Binet I.Q. of 120 in couples applying for artificial insemination. Interview, April 13, 1948. All other commentators have indicated concern for the intelligence of the couple although Barton, Walker and Wiesner have rejected the idea of artificial insemination being employed to produce a race of "supermen." Barton, Walker, Wiesner, note 15 supra.

40. See Seymour and Koerner, note 16 supra; Weisman, Selection of Dontors for Use in Artificial Insemination, 50 WEST. J. SURGERY 142 (1942); Guttmacher, note 15 supra.

41. Ibid.

42. Drs. Seymour and Koerner make a point of looking into the matter of financial status. Interview, note 39 supra. But even though other writers have not expressly mentioned it, the fact may well be concealed within their more euphonic phrases of "marital adjustment," and "social integration."

43. All commentators stress this. See, for example, Guttmacher, Physicians' Credo, note 36 supra. 
physical, and emotional setup. ${ }^{44}$ Married men with children are preferred. The children provide a test of physiological factors and a focus for the donor's parental affection. ${ }^{45}$ And finally the profession has been placed on guard against donor and doctor fees likely to make cost a prohibitive factor. ${ }^{\perp 5}$

Despite this complex of regulation, the law remains a persistent hazard to the doctors' attempts to save couples, donors, children and themselves from the reality of severe social and legal complications. Detailed analysis of the problems involved suggests that legislative decision is the only ultimate solution. ${ }^{47}$ The status of all the parties must be revieved and made official; and if the related genetics and financial considerations are to be left in the shadowland of professional rule, this lacuna should be the product of purpose and not of default.

\section{The Problems of Legislation}

But as it now stands a legislator who would write specific provisions into a law on AID must look for guidance to little more than his own select prejudice. For all the questions of AID must turn on specific answers-on information from the anthropologist, biologist, psychologist, sociologist et cetera. And the answers of these men, where extant, are in fact not available to law-givers for want of a system of liaison with the social sciences.

For example, there is the basic question of whether AID should be inhibited-inhibited in terms of the persons who may practice it and the technicians who may administer it. Should unmarried women be prevented from having children by this technique? Here the psychologist and sociologist must attempt to evaluate such factors as raising a child in the absence of a male parent, the stigma on a child known to be a product of the new scientific technique, the probability of societal acceptance of that technique, the effect of AID on marriages, the real increase in happiness it will bring to unmarried women. ${ }^{48}$ Before permitting the practice even to married couples desiring to attempt AID these same specialists should have gauged whether the likely effect on the marriage and child would be so detrimental as to argue proscription of the procedure. And where only one member of a marital pair agrees to the practice, to the above problems would be added a variety of additional issues, some closely akin to those present when a

44. Weisman, note 40 supra.

45. Barton, Waiker, Wiesner, note 15 sspgra.

46. Guttmacher, Physicians' Crcdo, note 36 supra.

47. Both medical and legal commentators have reached this conclusion before See Tucker, Legal Problenis of Artificial Inscmination, 33 Wossen LAwyens' J. 57 (1947); Koerner, Medicolegal Considerations in Artificial Insemination, 8 LA. L. KEr. 484 (1918).

48. There is the alternative of treating this problem as twenty states are content to treat the problems of miscegenation, i.e., as a matter of parental, personal choice. The California Supreme Court expressly chose this course with respect to miscegenation in Perez v. Lippold, 32 A. C. 757 (Cal. 1948). See Note, Constitstionality of Anti-miscegenation Statutes, infra p. 472. 
child is born to a couple one spouse of which had insisted on the use of contraceptives. ${ }^{49}$

The law-giver would have to look to the criminologist for precise information on optimum enforcement techniques if the practice is to be administered by only a limited group of technicians. Will the simplicity and safety of the practice require novel methods for preventing nurses, veterinarians, druggists and even laymen from administering? And if administration is not to be limited, can controls of any nature be effective? Certainly the parties to AID should expect legal craftsmen to protect them with evidentiary regulations, recording devices and procedural safeguards whenever they have acted in compliance with societal consent.

A certain source of litigation with respect to AID might readily be foreclosed by legislation detailing the incidents of intestate succession. But should the social attitude of such legislation be to effect a complete integration of the AID child within a family pattern identical to that accorded to children related to each of the spouses? ${ }^{\text {so }}$ Would it be too serious an abuse of our concepts of property and its transmission down a bloodline to permit the fact of AID birth to remain totally secret with respect to inheritance from collateral relatives? An investigation of current folklore and mores by the anthropologist and sociologist could sensibly determine the cost of permitting a child born of AID to inherit through the lineal and collateral relatives of his mother and her spouse.

To the biologist, sociologist and anthropologist falls the problem of determining the possible consequences of alternative schemes for eugenics control. The questions involved here range from the simple query-can eugenics produce better children?-to more subtle societal interests-what would be the effect on marriages and normal children of the presence of an aristocracy of "better AID products"? And the lawyer must add to the above studies his estimate of how enactment of minimal IQ, racial, and physical demands for couple selection will relate to constitutional strictures against discrimination. ${ }^{51}$

49. The pioneering regulation of the medical profession insists that both spouscs agree to artificial insemination. The doctors have argued that there was a positive likelihood of producing genuinely unhappy marriages and unhappy home environments for children unless mutual consent was obtained. See note 43 stspra.

For a discussion of the somewhat similar problems incident to the use of contraceptives see, Contraceptives and Divorce Law, 95 L. J. 249 (1945).

50. This is the intestate scheme that is felt to be proper in the case of adoption. For a discussion of the considerations which dictate such a plan see Kuhlmann, note 32 supra.

51. While sterilization laws have generally been upheld as constitutional-Buck $v$. Bell, 274 U.S. 200 (1927), settled the federal constitutional question-it seems very probable that considerations designed not so much to avoid generations of morons as to provide generations of super-children by discriminating against people merely because they arc average or slightly sub-average might fail. The delegation of so broad an authority to private doctors alone might condemn it.

For a complete summary through 1940 of the sterilization statutes and court decisions 
While enactment of model legislation is urgently needed now, the lillihood of diversity among the statutes, if the several states are left to treat the issue, creates questions in the conflict of laws.

Commentators on conflicts have tended to mininize the power of a forum to refuse enforcement of a right acquired under the law of another state. Nonetheless, such a power exists and will in some instances override comity if a court feels that the nature of a foreign right contravenes the public policy of the state where enforcement is sought. The tests here only require that a court regard the right as "inherently vicious, wicked, or immoral" or one which, if judicially enforced, would present its people a "pernicious and detestable" example. ${ }^{52}$ For questions of sex and medicine these are procrustean rules. It therefore seems likely that parties depending on rights acquired in states sympathetic to AID should anticipate difficulty enforcing these rights in states opposed to the practice.

The question of domicile in conflict of laws also invites use of those traditional and here inappropriate legal norms of legitimacy and bastardy. In conflicts, domicile for the legitimate child is considered to be that of the biologic or adoptive father ${ }^{53}$ and for the bastard to be that of the mother. ${ }^{54}$ Resolution of this point in a case will easily, in the absence of legislation, force courts back into their bramblebush of obsolete referents to marriage and procreation. ${ }^{55}$

To deal effectively with any of these technical conflicts problems which our federal system insures we must return to the social scientist for answers to the real questions involved. For example, is the relationship of the individual to the various levels of existing government so subtle that the democratic process will not permit immediate moral issues to be decided nationally? And if moral decisions are better controlled by smaller political

thereon see, Hughes, Eugenic Sterilization in the United States, Supp. No. 162, Purure HEALTH REPORTS (1940).

52. Veytia v. Alvarez, 30 Ariz. 316, 247 Pac. 117 (1926); Loudis v. Standard Oil Co. of New York, 224 N. Y. 99, 120 N. E. 198 (1918).

53. Delaware, L. \& W.R.R. v. Petrowsky, 250 Fed. 554 (2d Cir. 1918); Bjornquist v. Boston \& A. R. Co., 250 Fed. 929 (1st Cir. 1918); Kennedy v. Ryall, 67 N. Y. 379 (1876). See Restatentent, Conflict of LaWs $\$ 30$ (1934).

54. Danbury v. New Haven, 5 Conn. 584 (1825); Glansman v. Ledbetter, 190 Ind. 505, 130 N. E. 230 (1921); Thayer v. Thayer, 187 N. C. 573, 122 S. E. 307 (1924). See Restatearent, CoNflict of Laws $\$ 34$ (1934).

55. Another conflicts problem, one common to adoption, will doubtless arise in cases turning on AID. That is, are intestacy rights a part of the adoptive status and thercfore controlled by the state of adoption, or are they merely incidental to the adogtion status? The majority rule holds that the full faith and credit clause only requires that a court recognize the adoption status of a child adopted in another state; the Constitution does not compel one state to recognize the law of another with respect to the effect of adoption on the scheme of intestate succession. The courts will very likely apply this rule to AID cases since the rationale that inheritance provisions are only an incidental feature of the law of adoption seems equally applicable to artificial insemination. See Kuhlmann, note 32 supra. 
units, how can we adjust provincial or parochial rules to accommodate the high degree of mobility and interdependency of the modern industrial state?

\section{CONCLUSION}

And so AID comes to typify a broader problem for church and court and legislating men. It is a case study in the technique of change. For even after growth and innovation are no longer branded as undesirable, there remains the task of formally and gracefully accommodating them within a culture. ${ }^{56}$ Historically the role of the law in this process has been simplethe pin pricks of an infinity of special instances gradually tatoo a pattern of acceptance for the onetime novel or bold.

And the law's response to the challenge of AID has been to follow this familiar methodology. For centuries a human want existed-escape from biologically imposed childlessness. Through the careful and intensive investigatory techniques which characterize the physical sciences, medicine made great stricles in coping with the matter, after which it offered its discoveries to society. From normal human frictions came litigation, and a handful of cases have been thrust before an unprepared judiciary. A group of different legal doctrines and varying rules designed with a view toward other issues and other ages have been intuitively reworked in a makeshift attempt to meet a current need. Though the problem must clearly be met, when as many as 4,000 AID children are presently alive in America, ${ }^{67}$ only two legislatures seem to have recognized the existence of AID, and here the bills, hastily conceived with no adequate supporting study, have died in committee. ${ }^{58}$

56. But the immature will defend against change, as a source of insecurity and anxiety. For an excellent example of such a defense in the field of legal thinking sce Note, 34 VA. L. REv. 822 (1948). Opposing change as an evil, this writer argued against the innovation of heterologous artificial insemination "because [AID] is entirely unnecessary . . . . bccause it is contrary to accepted standards of legitimacy and adultery." Id. at 824. But the most extreme example of his felt need for a static legal system was his argument that AID should be discouraged because it was "legally problematical," likely to be productive of uncertain legal consequences. Id. at 827 . It would seem impossible under this test for change ever to come to that cluster of immutable concepts which the author had confused with the law.

57. This estimate is based on Seymour's and Koerner's report of 3649 AID cases extant in 1941. See Seymour and Koerner, note 38 supra.

58. New York Sen. 745 (1948)

"A child born to a married woman by means of artificial insemination with the express or implied consent of her husband shall be deemed the legitimate, natural child of both the husband and his wife for all purposes, and such husband and wife and such child shall sustain toward each other the legal relations of parent and child and shall have all the rights and be subject to all the duties of that relationship including the rights of inheritance from each other."

Virginia Sen. 745 (1948)

"Children born as the result of artificial insemination.-Children born as the result 
The agencies concerned are not acting to enquire into the nature of their subject nor the ramifications of their acts. At no point in the structure of our lawgiving machinery are facilities available to study the complex individual and institutional aspects of the question. In law we demand precision in analysis, niceness of thought, and certainty of effect in inverse relation to the social complexity and import of the problem involved. The agencies of social regulation and their rubric, the law, still operate with a casualness unknown in small business and a carelessness impossible in any larger commercial enterprise.

At the outset it is necessary to establish a system for appraising the operation of our legal institutions-for reporting regularly on their success or failure in terms of the objectives they are designed to achieve. Given adequate financial support, the institutions of legal education, the bar associations and the existing organizations devoted to the social sciences, working in close liaison with the technical sciences would be able to ascertain the areas in which social change is occurring without corresponding legal adjustment. Socio-legal developments such as AID having been spotted, a detailed scientific, legal, and sociological study should be made, Brandeis briefs prepared, and model legislation drafted where needed. In the absence of or perhaps supplemental to such studies by private institutions, legislative action in the nature of the TNEC investigations has been shown to be eminently feasible in providing a factual basis for rational decision on issues of social control. It is to be hoped that the immediate problem of AID, and the haphazard legal treatment it has received will be seen as illustrative of the need for creating some system for measuring the effectiveness of our social regulation and for better adjusting it to the phenomenon of change.

of artificial insemination shall be considered the same as legitimate children for all purposes, if the husband of the mother consented to the operation." 